\title{
Manajemen Pembelajaran Tahfidz Al-Qur'an dalam Meningkatkan Mutu Siswa SMA Swasta Istiqomah, SMA Plus Al Ghifari dan SMA Alfa Centauri
}

\author{
Supriadi1, Ujang Cepi Barlian², Nandang Koswara ${ }^{3}$ \\ 1,2,3Sekolah Pascasarjana, Universitas Islam Nusantara Bandung, Indonesia \\ E-mail: supriadibm220@gmail.com, ujangcepibarlian@gmail.com, abahnandangkoswara@gmail.com
}

\begin{tabular}{l}
\hline Article Info \\
\hline Article History \\
Received: 2022-02-03 \\
Revised: 2022-02-22 \\
Published: 2022-03-01
\end{tabular}

Keywords: Management; Tahfidz Learning; School Urriculum; Student Quality.

\begin{abstract}
The purpose of this study was to determine the planning, organization, implementation, supervision of tahfidz learning to improve students and to find out the obstacles faced in the tahfidz learning process in order to find out the efforts to overcome these obstacles. This study uses an approach through analytical descriptive methods and uses interview, observation and documentation studies. The results show that the management of tahfidz learning has been made based on management as the functions carried out through planning, organizing, implementing and monitoring in it there are processes, but management that has not been carried out optimally, including planning, although planning has been carried out in advance, but not all private high schools in Bandung are complete in making learning tools ranging from syllabus, prota, promissory notes, lesson plans to learning evaluations, as well as calculating the effective time of face-to-face hours that are adjusted to the educational calendar. In organizing using an organizational structure, a special tahfidz learning program has not yet been made a special organizational structure. However, it has been carried out according to the main tasks and functions of each in the teaching and learning process.
\end{abstract}

\begin{tabular}{l}
\hline Artikel Info \\
\hline Sejarah Artikel \\
Diterima: $2022-02-03$ \\
Direvisi: 2022-02-22 \\
Dipublikasi: 2022-03-01
\end{tabular}

Kata kunci:

Manajemen;

Pembelajaran Tahfidz;

Kurikulum Sekolah;

Mutu Siswa. \begin{abstract}
Abstrak
Tujuan penelitian ini adalah untuk mengetahui perencanaan, pengorganisasian, pelaksanaan, pengawasan pembelajaran tahfidz untuk meningkatkan mutu siswa serta mengetahui kendala-kendala yang dihadapi dalam proses pembelajaran tahfidz AlQur'an agar dapat mengetahui upaya-upaya yang dilakukan dalam mengatasi kendalakendala tersebut. Penelitian ini menggunakan pendekatan kualitatif melalui metoda deskriptif analitik serta menggunakan teknik wawancara, observasi dan studi dokumentasi. Hasil temuan penelitian menunjukkan bahwa manajemen pembelajaran tahfidz sudah dibuat berdasarkan pengelolaan sebagaimana fungsi manajemen yang dilaksanakan melalui langkah perencanaan, pengorganisasian, pelaksanaan dan pengawasan yang di dalamnya terdapat proses penilaian namun masih terdapat pengelolaan yang belum seluruhnya terlaksana secara optimal, diantaranya pada perencanaan, walaupun sudah dibuatkan perencanaan terlebih dahulu, namun belum seluruh SMA swasta di Bandung lengkap dalam membuat perangkat pembelajaran mulai dari silabus, prota, promes, RPP sampai evaluasi pembelajaran, serta penghitungan waktu efektif jam tatap muka yang disesuaikan dengan kalender pendidikan. Dalam pengorganisasian menggunakan struktur organisasi, belum dibuatkan struktur organisasi khusus program pembelajaran tahfidz secara tersendiri. Namun sudah terlaksana sesuai tugas pokok dan fungsi masing-masing dalam proses belajar mengajar (PBM).
\end{abstract}

\section{PENDAHULUAN}

Pendidikan merupakan salah satu upaya yang dapat mempercepat potensi manusia untuk mampu mengemban tugas yang sangat mulia sebagai pemimpin di muka bumi, karena hanya manusia yang dapat dididik dan mendidik, pendidikan dapat mempengaruhi perkembangan fisik, mental, emosional, moral, keimanan dan ketakwaan manusia, karena ketakwaan manusia di sisi Allah merupakan derajat yang paling mulia. Manusia sebagai makhluk ciptaan Allah yang berbeda dengan makhluk lainnya, tentunya diciptakan berdasarkan grand design Allah yang luar biasa, manusia diciptakan untuk tujuan beribadah dan dinobatkan oleh Allah sebagai khalifah yang memiliki berbagai kelebihan di antaranya adalah ilmu. Ilmu adalah kekuatan besar Islam dan kaum muslimin, karena dengan ilmu Allah akan meninggikan derajat kaum muslimin, pendidikan dalam Islam adalah kegiatan yang dilakukan dengan menggunakan cara-cara dan sarana-sarana yang tidak bertentangan dengan syari'at Islam untuk maksud memelihara serta membentuk seseorang menjadi pemimpin di muka bumi dengan kepemimpinan yang di atur berdasarkan peribadatan hanya 
kepada Allah ta'ala secara sempurna, sumber dasar pendidikan dalam Islam adalah Al-Qur'an dan Al-Hadits karena keduanya merupakan sumber dan dasar untuk menjalani kehidupan di dunia ini. Oleh karena itu sebagian kaum muslimin mengingin-kan anak sholeh dengan cara memasukkan putra dan putrinya ke sekolah yang berbasis Al- Qur'an.

Diantara bentuk interaksi kita dengan AlQur'an adalah membacanya, menghafalkannya, memahami isi kandungannya, mentadaburinya dan mengamalkannya. Interaksi dengan $\mathrm{Al}$ Qur'an dengan berbagai bentuk tidak diragukan lagi merupakan aktivitas yang mulia karena Allah menjanjikan banyak keutamaan dan kebaikan didalamnya, keutaman tersebut diantaranya perniagaan yang tidak pernah merugi, akan memperoleh pahala yang banyak, termasuk sebaik-baik manusia, mendapatkan syafa'at pada hari kiamat, pencapaian anugerah yang lebih baik daripada harta dunia, perumpamaan seorang mukmin yang membaca Al-Qur'an seperti buah utrujah, aromanya sedap dan rasanya lezat, Allah akan meninggikan derajat sebagian kaum dengan Al-Qur'an. Memasuki abad XXI, lembaga pendidikan Islam memikul tanggung jawab yang sangat berat karena dituntut untuk dapat menghasilkan output atau lulusan yang mampu meningkatkan kualitas kehidupan tidak hanya bagi dirinya tetapi juga untuk masyarakat bangsa dan negaranya. Salah satu output yang diharapkan adalah tertanamnya kepada siswa kegemaran membaca, baik membaca Al-Qur'an atau membaca ilmu pengetahuan yang lain. Sistem pendidikan Indonesia yang telah dibangun dari dulu sampai sekarang ini, ternyata masih belum mampu sepenuhnya menjawab kebutuhan dan tantangan global untuk masa yang akan datang, Program pemerataan dan peningkatan kualitas pendidikan yang selama ini menjadi fokus pembinaan masih menjadi masalah yang menonjol dalam dunia pendidikan di Indonesia saat ini.

Dewasa ini di Indonesia sudah terlihat tandatanda menurunnya kualitas moral dan mutu pembelajaran termasuk di kalangan siswa. Kondisi inilah yang menuntut pendidikan karakter harus segera diselenggarakan di semua jenjang pendidikan mulai usia dini sampai pendidikan menengah, terutama pendidikan karakter yang mengintergrasikan nilai-nilai $\mathrm{Al}$ Qur'an dan As-Sunnah kedalam semua materi pelajaran. Sub-Sistem utama yang berperan serta menentukan mutu suatu lembaga pendidikan adalah guru yang mengelola proses pembelajaran. Karena proses pembelajaran yang baik akan mampu mengantar peserta didik menjadi manusia berkualitas sesuai dengan kriteria yang telah diuraikan dalam undang-undang yang mengatur sistem pendidikan nasional diatas, guru di wajibkan memahami berbagai variasi metode pembelajaran sesuai dengan situasi dan kondisi serta karakteristik peserta didik ataupun kelas yang dihadapinya. Pendidik yang dapat mengelola kelas dengan baik dan menciptakan suasana belajar yang kondusif menunjukan kualitas pembelajaran yang baik, peserta didik sendiri merupakan 'partner' bagi pendidik, karena peserta didik memiliki peran yang sangat esensial bagi sebuah lembaga pendidikan, tanpa adanya peserta didik dipastikan tidak akan adanya guru. Oleh karena itu pendidik dan peserta didik berkolaborasi dalam menciptakan suasana kelas yang kondusif dan nyaman untuk mencapai tujuan pembelajaran.

Namun demikian, mutu proses pembelajaran di Indonesia sendiri masih rendah, hal ini dapat dilihat delapan standar nasional pendidikan yang masih belum sepenuhnya terpenuhi. Standar proses merupakan isu sentral yang berkaitan dengan mutu pendidikan yang rendah. Guru yang belum mampu mengelola proses pembelajaran merupakan salah satu faktor sulitnya mencapai standar proses dalam standar nasional pendidikan. Mutu pembelajaran Tahfidz AlQur'an di SMA pun masih rendah, hal ini dilihat dari sebagian besar lulusan yang belum bisa membaca Al-Qur'an dengan baik dan benar serta belum mampu menghafal Al-Qur'an sesuai target yang telah ditetapkan oleh lembaga masingmasing sekolah, padahal kemampuan membaca dan menghafal Al-Qur'an adalah modal bagi mereka dalam menjalani kehidupan di dunia dan sekaligus sebagai bekal untuk kehidupan akhirat yang kekal abadi. Berbagai permasalahan dalam pembelajaran Tahfidz Al-Qur'an dalam meningkatkan mutu siswa tersebut menuntut guru untuk menggunakan model pembelajaran yang dapat memfasilitasi tercapainya tujuan pembelajaran Tahfidz Al-Qur'an yang berorientasi pada kompetensi kemahiran dalam menulis, membaca dan menghafal Al-Qur'an dengan baik dan benar sesuai dengan kaidah ilmu tajwid. Seseorang yang memiliki kompeten-si menulis, membaca dan menghafal Al-Qur'an tersebut dapat meraih keberhasilan secara personal maupun profesional yang bisa di-implementasikan dalam kehidupan sehari-hari dan bisa dirasakan manfaatnya oleh masyarakat sekitarnya, maka 
dilaksanakan penelitian yang melibatkan tiga SMA Kota Bandung, yaitu SMA Istiqomah, SMA Plus Al Ghifari dan SMA Alfa Centauri Bandung. Ketiga SMA ini dipilih karena menerapkan pembelajaran tahfidzul Qur'an masuk kedalam muatan lokal, bidang Tahfidzul Qur'an tentunya menuntut siswa dapat menghafal beberapa juz dari Al-Quran dengan lancar secara lisan maupun tulisan yang dipraktekkan dalam kehidupan sehari-hari.

\section{METODE PENELITIAN}

Penelitian ini merupakan penelitian kualitatif analitis, penelitian ini termasuk juga field reseach yang sumber datanya diperoleh langsung dari lapangan (Bisri, 2004:56). Penelitian yang bersifat analitis, bertujuan menggambarkan secara tepat sifat suatu individu, keadaan, gejala atau kelompok tertentu atau untuk menentukan frekuensi atau penyebaran suatu gejala dan gejala lain (Sugiyono, 2004: 21). Dalam hal ini mungkin sudah ada pertanyaan-pertanyaan, mungkin belum, tergantung dari sedikit banyaknya pengetahuan tentang masalah yang bersangkutan, khususnya yang menjadi fokus penelitian (Sugiyono, 2014: 1-10), dalam proses penelitian ini, peneliti merupakan bagian dari instrumen penelitian dan analisis data dilakukan dengan pendekatan induktif kualitatif. Penggunaan metode analitik dengan pendekatan kualitatif ini bertujuan untuk menganalisis realitas objek yang diteliti (Al-Wasilah, 2008: 78). Penelitian ini, tidak hanya terbatas pada pengumpulan data, tetapi juga meliputi menganalisis dan menginterpretasikan data, serta membandingkan persamaan dan perbedaan fenomena yang ditemukan. Karakteristik metode penelitian ini dijadikan acuan dalam seluruh proses penelitian. Adapun teknik pengumpulan data yang digunakan dalam penelitian ini dilakukan melalui beberapa cara yaitu observasi, wawancara dan studi dokumentasi.

Penelitian difokuskan pada 3 (tiga) Subjek yang dipilih, untuk mewakili tujuan penelitian adalah SMA Istiqomah yang beralamat di kompleks Puragabaya No.14 L. ijawura Girang, SMA Plus Al Ghifari JL. Pengairan No. 23 Kelurahan Cisaranten Kulon Arcamanik Bandung dan SMA Alfa Centauri JL. Diponegoro No. 48 Bandung, dengan demikian dapat dilihat bahwa kompetensi menghafal Al-Qur'an merupakan kompetensi yang sangat penting dimiliki oleh siswa SMA.

\section{HASIL DAN PEMBAHASAN}

\section{A. Hasil Penelitian}

1. Deskripsi Hasil Penelitian di SMA Istiqomah Bandung

Perencanaan (Planning) adalah proses kegiatan yang menyiapkan secara systematis dari sebuah kegiatan yang dilakukan melalui rapat yayasan dan dewan guru tahfidz untuk menentukan tujuan yang ingin dicapai, dalam merencanakan Program Tahfidzul Qur'an, SMA Istiqomah memperhatikan dasar, target, materi, alokasi waktu serta perangkat pembelajaran. Dasar program pembelajaran tahfidz tertuang dalam SK Yayasan Istiqomah Bandung dan dalam standar kompetensi lulusan (SKL) dengan standar pencapaian, muatan jam pelajaran beralokasi waktu 3 jam pelajaran, kemudian target lulus hafal 3 juz, yaitu juz 30 di kelas X, juz 29 di kelas XI dan juz 28 di kelas XII, program tahfidz ini juga diperkuat dengan muroja'ah (mengulang kembali) pada waktu pagi hari sebelum memulai pelajaran dan pada akhir menjelang kepulangan, diharapkan agar alumni SMA Istiqomah Bandung mampu menjadi imam sholat di lingkungan masyarakat. Materi yang diberikan adalah materi bagaimana untuk bisa membaca AlQur'an dan bagaimana menghafal Al-Quran dengan alokasi waktu 3 x 40 menit per minggu, sementara perangkat perencanaan pembeljaran sudah dipersiapkan mulai dari silabus, prota, promes, RPP sampai evaluasi pembelajaran, termasuk juga peng-hitungan waktu efektif yang disusun dan dijadikan satu bendel dalam lembar portofolio pembelajaran Tahfidz dan diserahkan kepada waka kurikulum. Selanjutnya direncanakan dengan program ekstrakurikuler, kajian tiap rutin tiap bulan, program percepatan mem-baca Al-Qur'an, pesantren kilat, duta sekolah yang dikirim ke beberapa Masjid selama 10 hari untuk menjadi imam masjid program ini dilaksanakan di bulan Ramadan khususnya kelas XII.

Dalam pengorganisasian pembelajaran tahfidz di SMA Istiqomah Bandung, pengorganisasian menyatu dengan struktur organisasi sekolah, belum dibuatkan struktur organisasi secara tersendiri mengenai program tahfidz, satu orang guru tahfidz akan ditunjuk oleh sekolah sebagai koordinator guru tahfidz dan sisanya 
anggota. Koordinator tahfidz akan mengkoordinir semua hal yang terkait dengan pembelajaran tahfidz dan pembagian tugas. Pada proses pembelajaran di kelaspun terdiri dari tiga guru dan itu untuk mengkoordinir atau memantau pembelajaran, sistemnya seperti mentoring, setiap kelompok ada mentornya, dan setiap guru akan memonitor kelompok tahfidz setiap kelasnya, dan setiap kelas ada tiga kelompok tahfidz. Secara terkooordinir, setiap guru tahfidz akan memegang miniman 10 siswa dari total 30 siswa perkelas, yang disesuaikan dengan jumlah siswa setiap kelas, satu kelompok siswa diampu oleh 1 guru tahfidz.

Pada pelaksanaan pembelajaran tahfidz di SMA Istiqomah, ditemukan bahwa pembelajaran tahfidz dalam proses pembelajaran dilaksanakan di dalam kelas yang pelak-sanaannya oleh tiga orang guru yang meng-koordinir atau memantau pembelajaran, sistem yang digunakannya adalah seperti sistem mentoring, peserta didik dibagi menjadi beberapa kelompok yang setiap kelompok terdapat mentornya, kemudian setiap guru akan memonitor kelompok tahfidz di setiap kelasnya, dan setiap kelas ada tiga kelompok tahfidz. Setiap guru tahfidz akan memegang miniman 10 siswa dari total 30 siswa perkelas, yang disesuaikan dengan jumlah siswa setiap kelas. Satu kelompok siswa diampu oleh 1 guru tahfidz, satu peserta didik diberikan pembelajaran dimana guru benar-benar memperhatikan dan menyimak dengan seksama bacaan Al-Qur'an siswa, tidak bisa disamakan dengan mata pelajaran lain yang disampaikan secara klasikal.

Dalam upaya pengawasan terhadap pelaksanaan pembelajaran tahfidz AlQur'an, dipantau langsung oleh pihak yayasan, melalui pelaksanaan harian oleh guru tahfidz sebagaimana rapat koordinasi secara rutin dengan pihak yayasan, dalam hal ini ketua bidang pendidikan, sesuai harapan dari pihak yayasan, yakni harus ada program unggulan dari SMA Istiqomah yang diakhiri dengan wisuda Tahfidz AlQur'an untuk pembagian sertifikat dan ijazah tahfidz yang secara langsung dipantau langsung oleh pihak yayasan. Pada pengawasan yang di dalamnya terdapat evaluasi ini, tim guru tahfidz berkoordinasi langsung dengan pihak yayasan. Pengawasan atau pengendalian ini dilanjutkan dengan berkumpul dalam rapat secara berkala baik bulanan ataupun ketika persiapan wisuda tahfidz, sebelum wisuda tahfidz ada kegiatan mabit di sekolah, wisuda tahfidz dibagi dua yaitu wisuda tahfidz secara klasikal di sekolah dan wisuda tahfidz Yayasan yang diambil dari setiap jenjang dan dikhususkan bagi siswa yang memiliki hafalan yang mumpuni.

Pada penelitian ini ditemukan data bahwa faktor pendukung pembelajaran tahfidz di SMA Istiqomah Bandung ini memperoleh dukungan secara langsung dari yayasan, bukti daya dukung yang diberikan diantaranya adalah meningkatkan kompetensi guru tahfidz dengan memfasilitasi para guru tahfidz untuk mengikuti pelatihan yang dibiayai yayasan langsung di luar anggaran sekolah. Yayasan memiliki program khusus untuk para guru tahfidz dari semua unit, tidak hanya di sekolah masing-masing tetapi yayasan juga memberikan dukungan untuk meningkatkan kemampuan para pengajar tahfidznya salah satunya melalui kompetensi pelatihan tahfidz untuk guru tahfidz, untuk meningkatkan ruhiah siswa dengan mabit, wisuda dan lain-lain yang didukung sepenuh-nya oleh pihak yayasan, yayasan juga memberikan dukungan untuk meningkatkan kemampuan para pengajar tahfidznya, di-antaranya melalui kompetensi pelatihan tahfidz untuk guru tahfidz, untuk me-ningkatkan ruhiah siswa dengan mabit, wisuda dan lain-lain yang didukung sepenuhnya oleh pihak yayasan. Pada faktor penghambat pembelajaran tahfidz di SMA Istiqomah ditemukan bahwa terdapat beberapa faktor penghambat, diantaranya adalah input siswa yang beragam, latar belakang siswa dari sekolah umum yang di SMP nya tidak ada pelajaran tahfidz, masih ada pula yang belum bisa membaca $\mathrm{Al}$ Qur'an dengan baik sesuai kaidah ilmu tajwid dan agak sulit beradaptasi dengan pelajaran tahfidz, ada pula siswa yang tidak suka meng-hafal Al Qur'an sehingga perlu diadakan bimbingan intensif dalam membaca Al-Qur'an setelah lancar membaca Al Qur'an kemudian dapat dilanjutkan dengan menghafal. 
2. Deskripsi Hasil Penelitian di SMA Plus AlGhifari Bandung

Hasil temuan di SMA Plus Al- Ghifari bahwa perencanaan pembelajaran tahfidz sudah direncanakan dan sinergi dengan visi dan misi sekolah namun guru belum membuat RPP, Silabus, Program Semester dan Program Tahunan, ditemukan pula bahwa perencanaan agar setiap guru akan berkoordinasi terhadap perkembangan prestasi hafalan siswa, bagi siswa yang belum bisa membaca Al Quran akan mengikuti program PKBQ (Percepatan Kemampuan Membaca Al-Qur'an) yang sifatnya wajib diikuti oleh siswa direncanakan pula ada program khusus dengan diadakan-nya club tahfidz dan tahsin di luar kelas, target jangka panjang juz 29, 28 dan 27. Kurikulum tahfidz diterapkan di SMA Al-Ghifari baru juz 30, dengan rincian kelas 10 siswa fokus belajar ilmu tahsin dan tajwid, kelas XI dan XII siswa baru mulai menghafal Al-Qur'an, kelas IX mulai menghafal dari surat AlBuruj sampai surat An-Naas dan kelas XII menghafal Al_Qur'an surat Al-Insyiqoq sampai surat An-Naba, jumlah jam mata pelajaran tahfidz perpekan 2 jam mata pelajaran yang dilaksanakan secara klasikal perkelas jumlah siswa 30 perkelas. Pada pengorganisasian tahfidz di SMA Plus Al-Ghifari, peng-organisaian masih menyatu dengan struktur organisasi sekolah, belum mempunyai peng-organisasian khusus program tahfidz, untuk team pengembang visi dan misi team yang terdahulu, di bawah waka kurikulum. Pengorganisasian diberikan langsung sesuai tugas mengajar kepada guru, setiap guru tahfidz akan memegang miniman 10 siswa dari total 30 siswa perkelas, yang disesuaikan dengan jumlah siswa setiap kelas, satu kelompok siswa diampu oleh 1 guru tahfidz.

Pelaksanaan pembelajaran tahfidz AlQur'an di SMA Al-Ghifari, pelaksanaan pembelajaran tahfidz Al-Qur'an dilaksanakan setiap pagi, siswa membaca AlQur'an yang dilaksanakan bersamaan dengan sholat Dhuha, ketika siswa diberikan tugas dalam satu pekan menghafal surat tertentu maka surat yang dihafal akan dibacakan oleh siswa secara berjama'ah ketika sholat dhuha. Melalui pengulangan baik di waktu sholat ataupun diluar sholat siswa akan secara otomatis akan mudah menghafal dengan ayat yang didengarnya. Setiap hari dari jam 06.3007.00 WIB. Siswa tadarus Al-Qur'an dengan memperbaiki bacaannya yang dibimbing langsung oleh guru tahfidz, walaupun tanpa penjelasan ilmu tajwid guru tahfidz akan mempraktekkan langsung dalam pengajaran yang berkaitan dengan tahsin dan tajwidnya, hal ini didukung pula dengan pengadaan buku prestasi tahfidz siswa. Metode yang digunakan menggunakan lima metode, yakni metode tikror, yakni metode pengulangan ketika pengajaran guru tahfidz akan mencontohkan satu ayat-satu ayat sampai benar-benar siswa hafal dari ayat yang dibacakan dan dibimbing langsung oleh guru tahfidz, metode Talqin, guru membaca siswa mengikuti, metode sabak manzil yaitu metode yang dipasangkan satu siswa dengan siswa yang lain untuk saling menyetorkan hafalannya, metode ini sangat membantu guru tahfidz dalam proses setoran hafalan, siswa yang memiliki kelebihan dalam hafalan yang akan mem-bantu guru dalam proses PBM. Kemudian metode tasmi' yaitu satu siswa membacakan surat Al-Qur'an guru dan siswa men-dengarkannya dan metode klasikal yaitu guru membacakan ayat-ayat Al-Qur'an, semua siswa dikelas akan mengikuti dan mem-perhatikannya.

Faktor pendukung pemelajaran tahfidz berdasarkan hasil temuan di SMA AlGhifari diperoleh data bahwa ada beberapa faktor pendukung pembelajaran tahfidz, diantaranya terhadap pembelajaran tahfidz adalah regulasi yayasan Al-Ghifari sebagai landasan payung hukum yayasan yang dijadikan sebagai rujukan pendidikan. Prestasi yang dihargai kepada siswa yang berprestasi dengan beasiswa, ada keterkaitan dengan proses pem-belajaran dengan ditunjukkan oleh buku prestasi tahfidz siswa. Selanjutnya SMA Al Ghifari bekerja sama dengan beberapa instansi dari luar dalam bidang umum, untuk memotivasi belajar yang berlaku untuk mata pelajaran tahfidz dan program khusus club tahfidz dan tahsin di luar kelas Hal ini merupakan suatu faktor pendukung, karena melalui kerjasama ini, menumbuh-kan motivasi belajar tahfidz bagi para siswa sehingga dapat membangun siswa yang bermutu tinggi. Faktor penghambat yang ditemukan, 
berdasarkan hasil temuan di SMA AlGhifari diperoleh data bahwa terdapat kendala yang dihadapi, diantaranya adalah masih terdapat siswa yang belum bisa membaca Al-Qur'an, selanjutnya ditemukan pula bahwa faktor penghambat lainnya adalah waktu yang terbatas untuk menghafal Al-Qur'an yang disediakan sekolah dengan bimbingan guru sepekan 1 kali 2 jam mata pelajaran, dimasa offline 1 jam, dimasa online tidak ada pembelajaran tahfidz.

3. Deskripsi Hasil Penelitian di SMA Alfa Centauri

Perencanaan pembelajaan tahfidz di SMA Alfa Centauri, berdasarkan hasil temuan diperoleh data bahwa pembelajaan tahfidz di SMA Alfa Centauri, yakni pada peren-canaan sudah tertuang dalam kurikulum yang dibuat, untuk mata pelajaran tahfidz sudah dimasukkan ke dalam muatan lokal dalam kurikulum saat awal pendirian SMA Alfa centauri pada tahun 2003. Ditemukan pula data bahwa pembelajaran tahfidz di SMA Alfa centauri sudah direncanakan guru dengan membuat perencanaan dalam RPP, penilaian, Silabus, Prota dan Prosem yang disesuai dengan khas sekolah guru, silabus dibuat sendiri sesuai dengan khas sekolah, karena mata pelajaran tahfidz tidak ada dikurikulum nasional. Selanjut-nya perencanaan setiap kelas dibagi menjadi 3 kelompok yang disesuaikan dengan kemampuan siswa, ada siswa yang memiliki kemampuan tingkat cepat bagaimana perencanaan dan target yang akan dicapai, kemampuan sedang dan kemampuan lambat. Pengorganisasian tahfidz di SMA Alfa Centauri masih menyatu dan mengfungsikan struktur organisasi sekolah, belum adanya pengorganisasian khusus program tahfidz, satu tingkat ada tiga orang guru tahfidz, jadi jumlah guru tahfidz ber-jumlah 9 orang, setiap satu kelas dikerjakan oleh tiga guru tahfidz. Penorganisasian dari manajemen sekolah tahfidz masuk kedalam jam mata pelajaran sekolah, setiap kelas ada beberapa kelompok, ada target dan diakhir kelas tiga ada ujian munaqosyah yang wajib diikuti oleh semua siswa. Pihak sekolah menunjuk satu koordinator guru tahfidz untuk masuk ke MGMP guru mata pelajaran, guru koordinator tahfidz akan menyampaikan program ke setiap guru tahfidz berkaitan dengan teknis pembelajaran tahfidz per-kelas. Team guru tahfidz menyusun prota, prosem, silabus, RPP dan materi ajar yang bekerja sama dengan guru tahfidz yang lain.

Pelaksanaan pembelajaran tahfidz di SMA Alfa Centauri, berdasarkan hasil temuan bahwa pelaksanaan pembelajaran tahfiz dimulai dari manajemen sekolah tahfidz masuk ke dalam jam mata pelajaran sekolah, setiap kelas ada beberapa kelompok, ada target dan diakhir kelas tiga ada ujian munaqosyah yang wajib diikuti oleh semua siswa. Jika di kelas guru tahfidz akan membuat, metode dan materi. Melalui apersepsi guru dalam menyampaikan materi kepada siswa, tujuan dan kegiatan pem-belajaran yang akan dicapai pada hari tersebut. Surat yang akan dihafalkan hari ini surat apa, berapa ayat, sampai kegiatan penutupnya ada evaluasi, post tes, ulangan harian. Sementara metode tahfidz yang digunakan adalah metode TES yaitu Tilawah Evaluasi Sederhana yaitu siswa akan fokus membaca Al-Qur'an pada juz yang telah ditentukan. Walaupun belum memiliki metode khusus dalam membaca Al-Qur'an tetapi lebih kepada pencarian guru yang memiliki sanad dalam bacaan AlQur'annya.

Faktor pendukung yang ditemukan pada penelitiian ini bahwa pembelajaran tahfidz diantaranya adalah sudah ada dukungan dari pihak yayasan yang dibuktikan dengan dibangunkannya gedung khusus lantai 5 untuk kegiatan tahfidz, kemudian pihak sekolah menyediakan fasilitas touchscreen/tv besar, fitur pembelajaran yang didalamnya sudah lengkap, sehingga berdasarkan dukun-gan dan perhatiannya ini, yayasan cerdas, kretaif, mandiri memfasilitasi fitur tersebut untuk mempermudah guru dalam memberikan penjelasan materi ajar kepada siswa. Faktor penghambat lainnya adalah kurangnya perhatian, dukungan dan kerjasama dengan orangtua sebagai pendidik di lingkungan keluarga, disamping lingkungan masyarakat yang sangat berpengaruh sehingga agama siswa ditentukan dengan siapa siswa tersebut bergaul, melalui pembelajaran tahfidz ini akan meningkatkan mutu siswa dalam pelajaran lainnya. Trisula pendidikan dibangun atas kerja sama yang baik antara siswa di sekolah, di 
rumah dan dilingkungan masyarakat sekitarnya.

\section{B. Pembahasan}

Berdasarkan interpretasi dapat peneliti paparkan bahwa perencanaan manajemen pembelajaran tahfidz untuk meningkatkan mutu siswa SMA swasta di Bandung sudah dibuatkan perencanaan terlebih dahulu, karena perencanaan merupakan langkah awal dalam fungsi manajemen, walaupun belum seluruhnya SMA swasta di Bandung lengkap dalam membuat perencanaan perangkat pembelajaran secara tertulis dalam silabus, prota, promes, RPP dan evaluasi pembelajaran, serta penghitungan waktu efektif jam tatap muka yang disesuaikan dengan kalender pendidikan sebagaimana teori yang ada. Berdasarkan hal tersebut di atas, mengartikan bahwa perencanaam belum seluruhnya sesuai dengan PP RI No. 19 tahun 2005 bahwa "perencanaan proses pembelajaran memiliki silabus, perencanaan pelaksanaan pembelajaran yang memuat sekurang-kurangnya tujuan pembelajaran, materi ajar, meteode pengajaran, sumber belajar, dan penilaian hasil belajar". Perencanaan pembelajaran ini dibuat dengan tujuan untuk memberikan panduan dalam menyusun dan melaksanakan pembelajaran sebagai bahan evaluasi dan kontrol dalam penyusunan program pembelajaran. Menajemen pembelajaran tahfidz bermanfaat bagi guru, sebagai kontrol terhadap diri sendiri agar dapat memperbaiki cara pengajarannya SMA swasta di Bandung sudah terencana dengan memilih atau menentukan metode, materi, waktu yang dikembangkan di sekolah untuk diimplementasikan dalam proses pembelajaran, serta merencanakan SDM dalam pengelolaan dan pembelajaran tahfidz dengan diberi tugas pokok sesuai dengan fungsi masing-masing agar program dapat berjalan dengan baik serta mempertimbangkan waktu sekarang dan waktu yang akan datang untuk kegiatan yang akan dilaksakan di masa yang akan datang agar tercapai tujuan yang diharapkan, namun masih belum seluruhnya dituangkan dalam perangkat pembelajaran.

Dari hasil pembahasan tentang pengorganisasian pembelajaran tahfidz untuk meningkatkan mutu siswa SMA swasta di Bandung dapat dikatakan bahwa pengorganisasiannya masih mengikuti struktur organisasi yang ada di sekolah tersebut, belum mempunyai pengorganisasian tersendiri program tahfidz sehingga belum seluruhnya dilaksanakan sesuai teori yang ada, yang mengusahakan hubunganhubungan kelakuan yang efektif antara orang-orang, sehingga dapat bekerja sama secara efisien, dan memperoleh kepuasan pribadi dalam melaksanakan tugas-tugas tertentu, dalam kondisi lingkungan tertentu guna mencapai tujuan dan sasaran yang telah ditentukan dalam perencanaan mencapai tujuan yang diharapkan.

Pelaksanaan atau pengendalian pembelajaran tahfidz untuk meningkatkan mutu siswa SMA Swasta di Bandung ini dilaksanakan dengan apa yang direncanakan, namun belum seluruhnya guru dapat melaksanakan pembelajaran yang mengacu pada perangkat pembelajaran mulai silabus, RPP, prota dan promes sampai pada perencanaan dalam membuat perhitungan waktu efektif karena belum seluruh guru tahfisz di masing-masing sekola membuat perangkat pembelajaran tersebut. Pada pelaksanaan pembelajarannya, pembelajaran tahfidz, masuk ke dalam jam mata pelajaran sekolah sebagai muatan lokal dan diberikan sesuai dengan jam pelajaran layaknya pelajaran umum lainnya. Pembelajaran tahfidz dilaksanakan dengan metode khusus yang dianggap dapat lebih mudah menguasai hafalan Al-Quran sudah ditentukan dan digunakan setiap sekolah. Ditambah melalui tadarus Al-Qur'an serta murojaah dengan memperbaiki bacaannya yang dibimbing langsung oleh guru tahfidz. Pelaksanaan pembelajaran tahfidz apabila dikaji dari RPP, pelaksanaan proses pembelajaran merupakan implementasi dari RPP, berarti belum seluruhnya terlaksana meliputi kegiatan pendahuluan, inti dan penutup. Sementara untuk melaksanakan suatu pembelajaran, diperlukan perencanaan yang dibuat sesuai dengan apa yg dibutuhkan. Keberhasilan dari pelaksanaan pembelajaran sangat tergantung pada pelaksana pembelajar itu sendiri, kurikulum atau perangkat pembelajaran yang dibuat akan memiliki kemampuan dedikasi dan semangat yang tinggi maka hasilnya akan lebih baik. Sehingga dapat mengefektifkan segi waktu, metode, model dan materi pembelajaran dengan lebih efesien dan bermakna, terlebih bagi siswa yang belum bisa membaca Al-Quran sama sekali. 
Pelaksanaan pengawasan atau pengendalian pembelajaran tahfidz untuk meningkatkan mutu siswa SMA Swasta di Bandung ini dilaksanakan dengan tujuan untuk menentukan seberapa banyak tingkat pencapaian pelaksanaan pembelajaran tahfidz, penyimpangan-penyimpangan, hambatannya serta faktor pendukung terlaksananya pendidikan karakter sesuai tujuan atau harapan-harapan yang secara nyata dicapai sesuai perencanaan yang diharapkan dan melakukan perbaikanperbaikan apabila terjadi penyimpanganpenyimpangan. Pengawasan seharusnya melibatkan semua komponen yang ada di pengawasan terhadap kegiatan yang akan dilaksanakan. Sekolah dan dilaksanakan untuk meneliti kegiatan-kegiatan yang telah dilaksanakan dan yang akan dilaksanakan termasuk pengawasan oleh Kepala satuan pendidikan dan pengawas yang harus ikut mengawasi proses pembelajaran dalam kegiatan belajar mengajar siswa dan guru di sekolah.

\section{SIMPULAN DAN SARAN}

\section{A. Simpulan}

Berdasarkan penelitian yang telah dilakukan, maka dapat disimpulkan bahwa manajemen pembelajaran tahfidz SMA swasta di Bandung adalah:

1. Perencanaan pembelajaran tahfidz SMA swasta di Bandung, belum seluruhnya SMA swasta di Bandung membuat perencanaan perangkat pembelajaran secara tertulis dalam silabus, prota, promes, RPP dan evaluasi pembelajaran, serta penghitungan waktu efektif jam tatap muka yang disesuaikan dengan kalender pendidikan secara lengkap.

2. Pengorganisasian pembelajaran tahfidz SMA swasta di Bandung, pengorganisasian baru sebatas menggunakan pengorganisasian dalam struktur organisasi yang ada di sekolah, belum membuat struktur organisasi khusus pembelajaran tahfidz secara tersendiri.

3. Pelaksanaan pembelajaran tahfidz SMA swasta di Bandung sudah dilaksanakan sesuai dengan perencanaan yang dibuat tetapi belum seluruhnya terlaksana secara optimal, terutama dalam hal rasio jumlah tenaga pendidik dengan peserta didik serta sarana prasarana pendukung pem- belajaran tahfidz agar hasilnya lebih optimal dalam pencapaian tujuan.

4. Pengawasan pembelajaran tahfidz SMA swasta di Bandung dapat dikatakan bahwa proses pengawasan belum seluruhnya dilaksanakan pengawasan atau pengendalian pembelajaran tahfidz masih ada yang harus dikembangkan terutama dalam langkah-langkah pengawasan yang menyeluruh dari setiap personil, tidak hanya mengandalkan pengawasan penuh dari pihak yayasan atau kepala sekolah dan guru tahfidz saja sehingga terlaksana pengawasan yang dilanjutkan pada tahap penilaian, agar lebih real dan kooperatif serta shahih.

5. Upaya-upaya yang dilakukan dalam mengatasi kendala-kendala proses pembelajaran tahfidz Al-Qur'an SMA swasta di Bandung, sudah ada upaya dari pihak yayasan dalam mendukung, membiayai dan membantu serta meningkatkan komptensi guru tahfidz diantaranya dengan mengadakan pelatihan, meningkatkan ruhiah siswa dengan mabit, wisuda dan lain-lain, namun belum optimal sehingga perlu ditingkatkan lagi upayanya.

6. Kendala-kendala yang dihadapi dalam proses pembelajaran tahfidz SMA swasta di Bandung, diantaranya adalah dukungan orangtua, input siswa. Latar belakang siswa yang masuk dari sekolah umum yang tidak ada pelajaran tahfidz, belum bisa membaca Al Qur'an dengan baik sesuai kaidah ilmu tajwid. Berdasarkan hal ini kendala-kendala belum seluruhnya dapat diatasi secara optimal.

\section{B. Saran}

Berdasarkan temuan saat melaksanakan penelitian, adapun saran sebagai berikut:

1. Dinas Pendidikan

Adanya pengawasan dari pemerintah setempat, dan bagi Pemerintah harus memperhatikan kesejahteraan para guru tahfidz Al-Qur'an supaya tidak ada dikotomi dengan guru-guru mata pelajaran yang lainnya seperti dalam hal sertifikasi guru yang harus disejajarkan dengan guru mapel lainnya.

2. Yayasan

a) Perlu adanya dukungan dengan mempersiapkan tempat, media berbasis ICT cara mudah membaca dan hafalan Al-Quran serta perencanaan penamba- 
han SDM guru-guru tahfidz yang memiliki kompetensi guru tahfidz 30 juz dan memiliki bacaan Al-Qur'an yang bersanad akan memiliki ruh dalam pengajaran tahfidz di sekolah.

b) Bagi sekolah yang belum memiliki sarana khusus seperti masjid harus diperhatikan, karena tempat yang baik dalam menghafal Al-qur'an yaitu masjid sebagai rumah Allah.

3. Kepala Sekolah

a) Direkomendasikan bahwa perlu adanya perencanaan waktu dengan adanya penambahan jam pelajaran tahfidz dan ekstrakurikuler, karena alokasi waktu 2-3 jam per pekan akan menyebabkan hafalan mudah hilang dan sulit bagi siswa dalam mencapai hapalan yang lancar (mutqin) karena bacaan dan hafalan Al-Qur'an harus dibaca dan diulangi setiap hari.

b) Mengadakan penambahan guru tahfidz yang berkompeten yang disesuaikan dengan rasio siswa dan guru.

4. Guru Tahfidz

a) Mempersiapkan dan melengkai seluruh perangkat pembelajaran dan mencari atau menentukan metode tahfidz yang lebih tepat dan cepat dalam pencapaian tujuan. Metode tahfidz yang direkomendasikan adalah metode Taqlil dan Takrir.

b) Perlu adanya guru tahfidz khusus untuk menangani siswa yang belum bisa baca Al-Qur'an dengan diberikan motivasi secara kontinyu dan harus diberikan alokasi tambahan waktu khusus selama 1-3 bulan untuk bica mencapai target bisa membaca Al-Qur'an dengan tartil dan sesuai kaidah ilmu tajwid melalui metode cepat dan tepat membaca AlQuran sehingga tidak menghambat pengajaran tahfidz di kelas.

c) Memberikan reward and punishment bagi peserta didik yang konsisten hafalan

5. Peserta didik

a) Disarankan tidak mengganti-ganti mushaf atau ketika menghafal tidak melihat mushaf Al-Qur'an. Ketika menghafal harus berulang-ulang melihat ayat Al-Qur'an sehingga ayat demi ayat akan terekam dan tergambar dama benak fikirannya. b) Konsisten, ikhlas menghafal dan setia

6. Orangtua siswa

Dukungan orangtua direkomendasikan untuk meningkatkan hafalan dengan upaya secara bersama-sama ikut mengawasi dalam mengkaji, mengulang, membaca dan menghafal Al-Quran ketika di rumah.

\section{DAFTAR RUJUKAN}

Alwasilah, A. C. 2008. Pokoknya Kualitatif: Dasardasar Merancang dan Melakukan Penelitian Kualitatif. Jakarta: Pustaka Jaya

Asmedy, A. (2021). Perbandingan Hasil Belajar Matematika Siswa yang diajar dengan Model Pembelajaran Possing Problem Berkelompok dan Metode Ceramah. Jurnal Inovasi, Evaluasi Dan Pengembangan Pembelajaran (JIEPP), 1(2), 69-75. https://doi.org/10.54371/jiepp.v1i2.107

Bisri, C.H. 2004. Penuntun Penyusunan Rencana Penelitian dan Penulisan Skripsi. Jakarta: Bumi Aksara

Depdikbud, (2014). Strategi Belajar dan Pembelajaran Implementasi Kurikulum 2013. Jakarta: Depdikbud.

Nurhasanah, E. (2021). Pengaruh Media Pembelajaran Berbasis Flashcard Huruf Hijaiyah terhadap Hasil Belajar Iqro pada Santri The Gold Generation. Jurnal Inovasi, Evaluasi Dan Pengembangan Pembelajaran (JIEPP), 1(2), 60-68. https://doi.org/10.54371/iiepp.v1i2.106

Rinjani, C., Wahdini, F. I., Mulia, E., Zakir, S., \& Amelia, S. (2021). Kajian Konseptual Model Pembelajaran Word Square untuk Meningkatkan Hasil Belajar Siswa. Jurnal Inovasi, Evaluasi Dan Pengembangan Pembelajaran (JIEPP), 1(2), 52-59. https://doi.org/10.54371/jiepp.v1i2.102

Sugiyono. (2004). Metode Penelitian. Bandung: Alfabeta.

Sugiyono. (2014). Metode Penelitian Pendidikan Pendekatan Kuantitatif, Kualitatif, dan R\&D. Bandung: Alfabeta.

Terry, G.R. (2010). Dasar-dasar Manajemen. (Terje: G.A. Ticoalu). Jakarta: Bumi Aksara. 